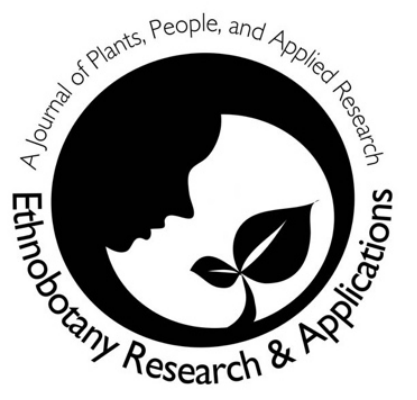

\title{
Ecological and ethnobotanical values of weeds found in the spring rice fields in Chitwan, Nepal
}

\author{
Niraj Prakash Joshi
}

\section{Correspondence}

Niraj Prakash Joshi

International Economic Development Program, Graduate School of Humanities and Social Sciences, Hiroshima University, 1-5-1 Kagamiyama, Higashi Hiroshima Shi, Hiroshima, Japan 739-8529

*Corresponding Author: nirajpjoshi@hotmail.com

Ethnobotany Research \& Applications 22:37 (2021)

\section{Databases and Inventories}

\begin{abstract}
Background: The reliance of human beings on plants for different purposes such as medicine, fodder, fuel, and shelter is fading away, primarily, due to increasing dominance of market economy globally in the recent decades. Ethnobotanical study, especially that of weeds, is playing a crucial role in establishing the relationship between weeds and people, thereby documenting important uses of such weeds. Chitwan, located in the central part of Terai, is considered the grain basket of Nepal. The district is relatively advanced in agriculture, with higher agricultural productivity than that in most of the country. Spring rice cultivation is prevalent in the area. Weed infestation is one of the severe problems adversely affecting rice cultivation. These weeds have different ethnobotanical values for indigenous ethnic groups as well as residents.
\end{abstract}

Methods: Ecological survey was carried out in four distinct sites: the rice fields of the Institute of Agriculture and Animal Science, Gitanagar, Champanagar, and Ujjalnagar of Chitwan, Nepal. Weeds were collected from three randomly placed one-square-meter quadrats in each rice field. The ethnobotanical uses of the weeds were explored via key informant surveys with traditional healers from Tharu and Darai ethnic groups and the Brahmin caste in Mangalpur, Gitanagar, Champanagar, and Ujjalnagar.

Results: Weed flora of 53 species belonging to 43 genera and 22 families were reported in the spring rice fields. Cyperaceae (twelve species), Compositae (five species), Fabaceae (four species), Linderniaceae (four species), Plantaginaceae (four species), Poaceae (four species), and Amaranthaceae (three species) were the families with the largest representation, accounting for approximately $68 \%$ of all weeds. The most common weeds were Spirodela polyrrhiza (L.) Schleid., Cyperus difformis L., Azolla Lam., Lindernia procumbens (Krock.) Philcox, Mecardonia procumbens (Mill.) Small, and Fimbristylis quinquangularis (Vahl) Kunth. These weeds also possess different ethnobotanical values, the most common being medicinal and fodder values.

Conclusions: This study reveals the significance of weeds as medicine along with their medicinal values. People still rely on such plants as a primary healing resource. In addition, weeds can be used as fodder for livestock and have other important uses in local daily life. Hence, there is a dire need to spread awareness regarding ethnobotanical uses of weeds found in spring rice fields in Chitwan. This can possibly contribute to the sustainable uses of weeds, rather than grossly eliminating them from the field, which poses a threat to their extinction. 


\section{Background}

It is well known that a crop grown alone cannot exist; some unwanted plant species also exist in the field that we call "weeds." These weeds compete with crops for light, space, water, and mineral nutrients resulting in low-quantity as well as low-quality grain production, thus adversely affecting human welfare (Dangol et al. 1988; Shrestha et al. 2018; Jaisi et al. 2020). Weeds and weed management is perceived as one of the severe problems in spring rice production in Chitwan (Jaisi et al. 2020). Losses in rice production alone range from $5 \%$ to $100 \%$ depending on the type of weeds, its intensity, and soil fertility (Dangol et al. 1988). Thus, there is a need of weed survey studies for their proper management to reduce losses caused by them. Such survey in Nepal can be traced back to 1965 when it was first conducted by M Numata in Eastern Nepal and followed by RL Chaudhary (1968 and 1971) in the southern part (Bhatt et al. 2021). Since then, several types of research have been conducted involving various crop fields across Nepal (Bhatt et al. 2021). Surveys of weeds in rice fields can also be found (Dangol et al. 1986; Dangol et al. 1988; Dangol \& Bhattarai 1993), but those for spring rice are largely missing.

Each plant, including weeds, has certain benefits. Different ethnic groups or societies use plants for different purposes. Beneficial uses significantly contribute to rural society (Manandhar 1997). In addition, the importance of ethnobotany to identify plant species for conservation and sustainable community development has been acknowledged in the literature (Rijal 1997; Shengji 1997; Shrestha 1997; Bhat 2019). Ethnomedicine based on traditional knowledge is a good example, contributing to poor communities' handling of different health issues (Singh et al. 2014; Amjad et al. 2015; Arunesh et al. 2018; Bhatt \& Kunwar 2020; Budha-Magar et al. 2020; Pangeni et al. 2020; Pradhan et al. 2020; Bhatt et al. 2021). Such uses are important, especially in rural areas where modern health care facilities are either unavailable or out of reach to the poor. Hence, such traditional knowledge (ethnomedicine), which can also be regarded as Ayurveda, herbal medicine, and traditional and complementary medicine, can significantly contribute to Sustainable Development Goal 3 (WHO, 2019). This justifies researching the ethnobotanical uses of weeds, which are otherwise discarded. Hence, this study records the weeds found in the spring rice fields and their ethnobotanical value for Chitwan's Tharu, Darai, and Brahmin ethnic/caste groups. Chitwan is among the few districts where rice, including spring rice, is intensively grown (MoALD 2020). The district is also a home for diverse caste and ethnic groups immigrated from all around the country including its own indigenous ethnic groups like Tharu and Darai. It is hypothesized that the weeds in spring rice fields and plants around the spring rice fields have ethnobotanical value for indigenous ethnic groups like Tharu and Darai as well as the Brahmins, an immigrant caste group, in the study area. The anecdotal evidence suggests that indigenous ethnic groups like Tharu and Darai possess rich traditional knowledge on plant uses. Similarly, Brahmins also use plants for different daily purposes. Since ethnobotanical studies of weeds in spring rice are largely missing, and ethnobotanical studies focus primarily on indigenous ethnic group, this study contributes to filling such research gap by studying the ethnobotanical uses of weeds reported in spring rice by Brahmins, besides two ethnic groups in Chitwan.

\section{Materials and Methods \\ Study area}

Chitwan is a centrally located developed district of Nepal in terms of infrastructure, transport, communication, and other facilities, alongside the implementation of improved agricultural technologies and practices. Most farmers are now engaged in agriculture year-round. They do not pursue rice cultivation only during the normal season (i.e., Aashad), but also during spring, which is known as "spring rice" (FAO 2002). Hence, rice is intensively grown in Chitwan during both seasons; monsoon (June-November) and spring (February-July), contributing to around 68\% of the district's cultivable area under cereal production (MoALD 2020). Chitwan is among the districts with the highest land area under spring rice cultivation.

After considering the prevalence of spring rice production, four locations in Chitwan district were selected for this study. Three settlements, namely, Gitanagar, Champanagar, and Ujjalnagar, in the then Gitanagar Village Development Committee (VDC) (approximately 27 $36^{\prime} \mathrm{N} 84^{\circ} 23^{\prime} \mathrm{E}$ with an elevation of 192 meters above mean sea level-masl), as well as farmland of the Institute of Agriculture and Animal Science (IAAS), located in the then Sharadanagar VDC (approximately $27^{\circ} 38^{\prime} \mathrm{N} 84^{\circ} 21^{\prime} \mathrm{E}$ with the elevation of 185 masl), were the four locations (Figure 1). After the restructuring of local governance in Nepal (2017), Gitanagar VDC and Sharadanagar VDC were merged with the then Bharatpur sub-metropolitan city to form the present Bharatpur Metropolitan City. These study settlements are now designated as Ward No. 6 (in the case of Gitanagar) and No. 13 (in the case of Champanagar and Ujjalnagar) of Bharatpur Metropolitan City. The farmland of IAAS is now located in Ward No. 19 of Bharatpur Metropolitan City. The IAAS farmland is low land with poor drainage or a swampy land. Waterlogging in the fields 
promotes weeds in the spring rice fields of IAAS farmland. In contrast, in the other three locations, water is properly managed in the spring rice fields. The main motive behind selecting the IAAS farmland as one of the four study locations is to represent the special case of spring rice field in swampy land as well in this study.

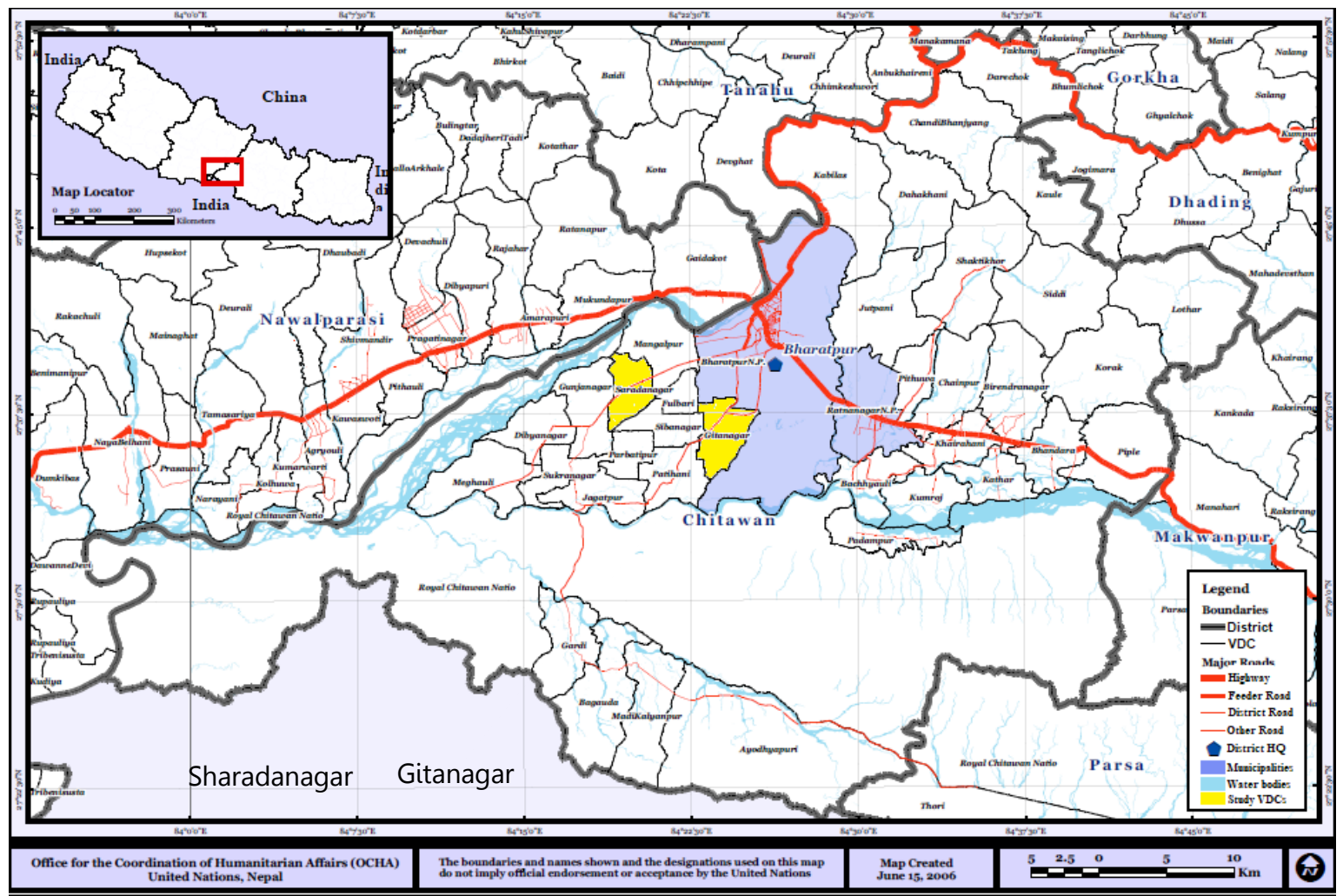

Figure 1. Map of Chitwan showing the study's Village Development Committees (UN 2006)

\section{Ecological study}

Spring rice growing season in Nepal is February/March to June/July, which in case of Terai and inner Terai is delayed by 2-4 weeks (MoAD, 2015). Hence, the ecological survey was carried out in four spring rice fields, one each at the IAAS farmland, Gitanagar, Champanagar, and Ujjalnagar, located in Chitwan, Nepal, in early July 2002, while the spring rice was still standing in the field.

Weeds were uprooted from an area within one-meter square quadrats randomly selected in three locations in each spring rice field. Herbarium sheets were prepared for each reported weed species by pressing each of them under a separate newspaper sheet in the field. Each of the herbaria was tagged for identification together with some of the characteristic features of those weeds such as habit, habitat, and flower color on the same page. All remaining weeds, uprooted from the quadrats, were collected in separate polythene bags. The species collected in polythene bags, representing different quadrats, were counted in an ecological analysis, more specifically, density, abundance, frequency, relative density, relative abundance, relative frequency, and importance value index (IVI) (Pancho \& Kim 1985; Zobel et al. 1987).

An expert in the Department of Agricultural Botany, IAAS, Chitwan, was consulted for the identification of weed species reported in the paddy rice fields using the herbariums and the noted characteristic features. A book titled Annotated checklist of the flowering plants of Nepal by Press et al. (2000) was used for cross-validation. The scientific name of the identified plant species and their families were updated referring to World Flora Online http://www.worldfloraonline.org/ (August 6, 2021) (WFO, 2021).

\section{Ethnobotanical survey and data analyses}

For the ethnobotanical survey, additional weeds/plants found up to around $3 \mathrm{~m}$ from the spring rice fields, which was set arbitrarily, were also collected. Herbarium of the collected weeds were prepared and identified along with the weeds reported in the spring rice field for the ecological survey. Ethnobotanical surveys of the weeds reported in and around the spring rice fields were conducted through key informant surveys. Eminent practitioners/healers 
in the vicinity of the spring rice fields were identified and considered for key informant interviews (ethnobotanical surveys). The key informants interviewed in August and early September 2002 included one from Tharu ethnic group (identified as NRM), in Bangain settlement, in Sharadanagar VDC; one from Darai ethnic group (identified as RBD), in Mangalpur settlement, close to IAAS farm; and two from Brahmin caste (identified as F.Ac. and M.Ad.), in Ujjalnagar settlement and Champanagar settlement, respectively. The key informants were fully informed regarding the research, and verbal consent was obtained to participate in the interview and publish the information provided, whenever applicable. Confidentiality was also maintained as per the ISE Code of Ethics (ISE 2006). All the key informants are well known in their localities as Vaidyas, traditional healers using plants. Thus, they knew the ethnobotanical uses of different plant species existing in their surroundings. The interview involved the use of a checklist that included the local name of the weeds collected from the quadrat surveys as well as plants/weeds collected from around the spring rice fields, and their ethnobotanical uses. For the plants having medicinal value, the checklist alone included methods of use and medicinal value. The collected information was qualitatively analyzed.

\section{Results and Discussion \\ Ecological analysis}

Fifty-three identified and one unidentified species belonging to 43 genera and 22 families were found in the surveyed spring rice fields (Figure 2). The reported number was close to that delineated by Manandhar et al. (2007) in the paddy field at Kirtipur, that is, 52 weed species. Among the 22 families, 15 come from Dicotyledonae, six from Monocotyledonae, and one from Pteridophyta (Azolla Lam). The families that contributed more species were Cyperaceae (twelve species), Compositae (five species), Fabaceae (four species), Linderniaceae (four species), Plantaginaceae (four species), Poaceae (four species), Amaranthaceae (three species), Lythraceae (two species), Polygonaceae (two species), and the rest of the families had one species each (Figure 2).

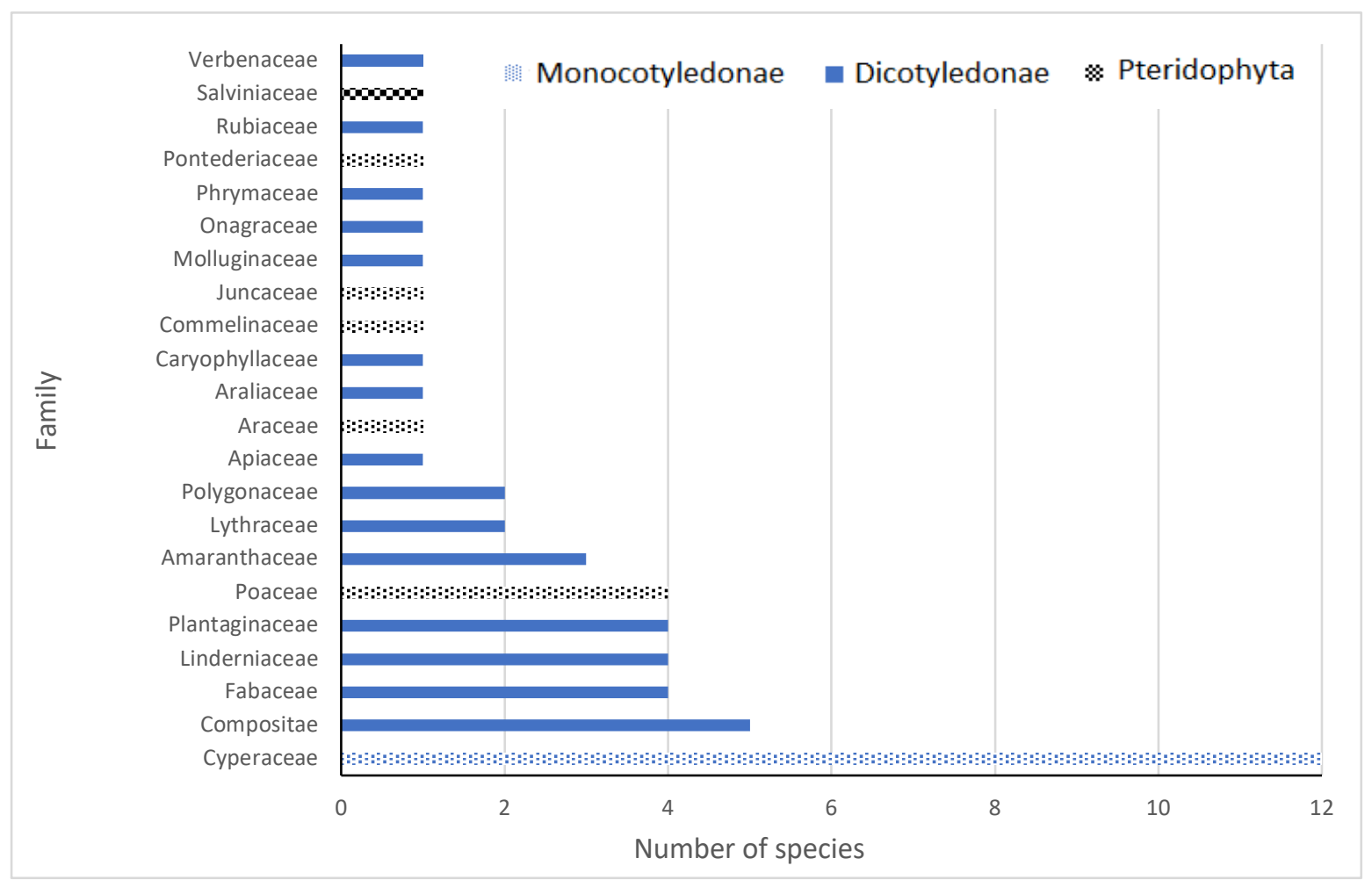

Figure 2. Number of species per family in the study sites

Among all these 53 species, Spirodela polyrrhiza (L.) Schleid., a monocot species belonging to the Araceae family, had higher density, abundance, relative density, and relative abundance, but the frequency and relative frequency were low, which indicates that these weeds were mostly found in Champanagar, Ujjalnagar, and Gitanagar; they were not found in the lowlands at the IAAS farm, which was marshy land. Azolla Lam. had a relatively higher abundance. Its occurrence was confined to the marshy land rice field of IAAS. Alternanthera sessilis (L.) R.Br. ex DC., Fimbristylis quinquangularis (Vahl) Kunth, Cyperus difformis L. and Lindernia procumbens (Krock.) Philcox were found throughout the study area. 


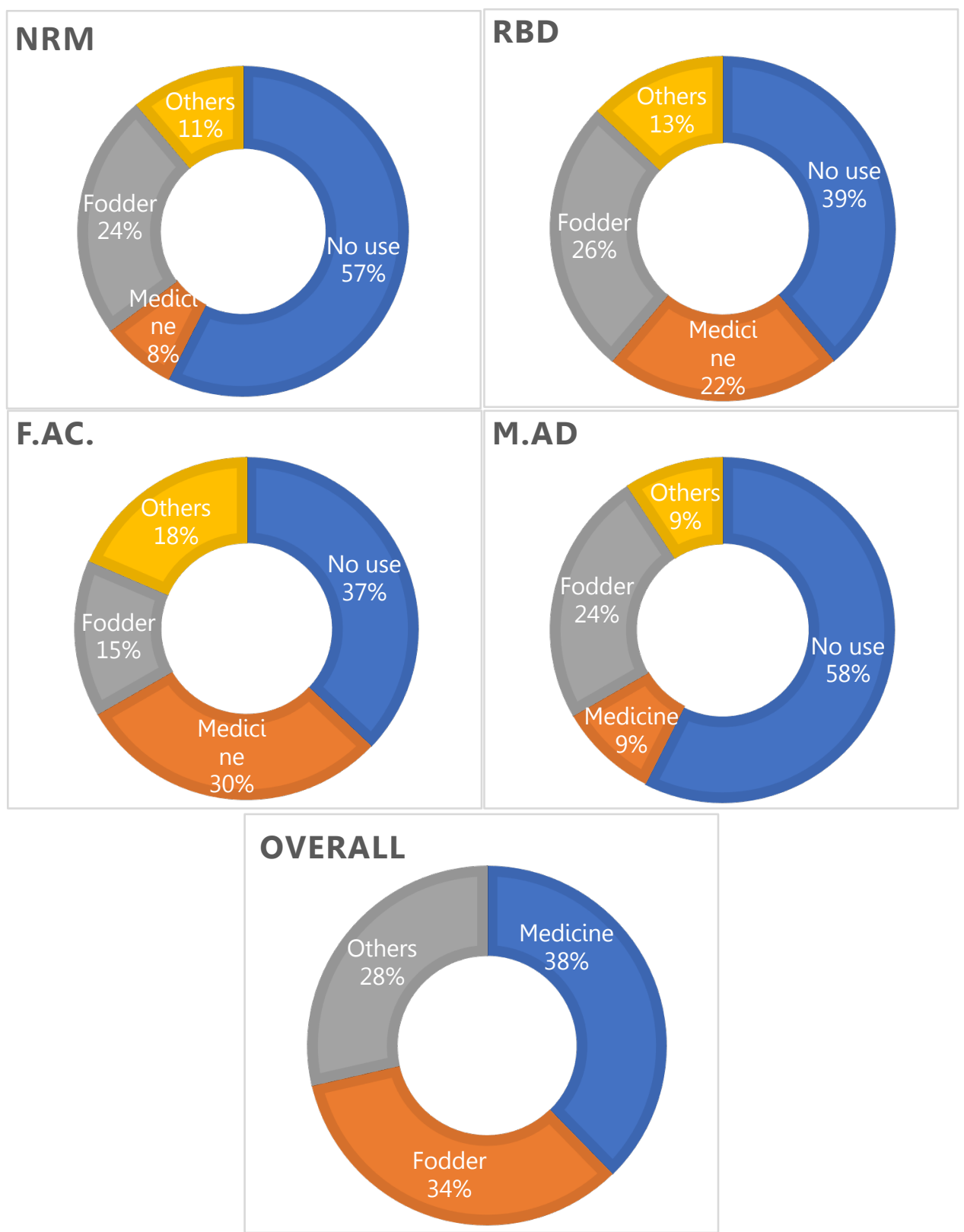

Figure 3. Distribution of ethnobotanical uses of the plants in and around the spring rice fields by different key informants

Based on $\mathrm{IVI} /$ summed dominance ratio (SDR), the plant species that predominate the spring rice fields were Spirodela polyrrhiza (L.) Schleid. (42.7 IVI/ 14.23 SDR), Cyperus difformis L. (32.1 IVI/ 10.69 SDR), Azolla Lam. (31.7IVI/ 10.55 SDR), Lindernia procumbens (Krock.) Philcox (23.8 IVI/ 7.92 SDR), Mecardonia procumbens (Mill.) Small (12.7 IVI/ 4.219 SDR), Fimbristylis quinquangularis (Vahl) Kunth (11.6 IVI/ 3.876 SDR) (Annex B). Among them, Cyperus difformis $\mathrm{L}$. and Lindernia procumbens (Krock.) Philcox were also reported in the paddy fields in Farwestern Nepal. Besides, Alternanthera sessilis (L.) R.Br. ex DC., Cynodon dactylon (L.) Pers., Echinochloa colona (L.) Link, Eclipta prostrata (L.) L., Eleocharis atropurpurea (Retz.) J. Presl \& C. Presl, Gratiola oppositifolia L. ex Willd. (syn. Lindernia oppositifolia (L.) Mukerjee), and Lindernia procumbens (Krock.) Philcox are also the weeds reported in the paddy fields in Nepal affecting paddy yield (Manandhar et al. 2007; Bhatt et al. 2021).

Mecardonia procumbens (Mill.) Small, Alternanthera sessilis (L.) R.Br. ex DC., Paspalum distihum L., and Ageratum houstonianum Mill., which have relatively higher IVI/SDR, are reported as "introduced (alien) and invasive alien species" to Nepal. Besides, other seven species also fall under the list of 183 "introduced (alien) and invasive alien species," namely, Schoenoplectiella supina (L.) Lye; Amaranthus spinosus L.; Eclipta prostrata (L.) L.; Ludwigia hyssopifolia (G.Don.) Exell; Chenopodium album L.; Scoparia dulcis L.; Senna tora (L.) Roxb. (Shrestha et al. 2020). 
All these eleven invasive species have no evidence of impact except Ageratum houstonianum Mill (GBIF Secretariat 2021). Ageratum houstonianum Mill is considered as highly problematic, resulting in several negative impacts on livelihoods of people, putting pressure on agriculture production, and forest regeneration. Moreover, there will be $+70 \%$ increase in suitable habitat for Ageratum houstonianum Mill for the period 2050 with respect to current climate, further aggravating the negative impacts in the future (Shrestha et al. 2018).

\section{Ethnobotanical uses}

Among the 53 species of the spring rice field weeds, 33 have ethnobotanical values for different ethnic/caste groups predominant in Chitwan (i.e., Tharu, Darai, and Brahmin). In addition, 21 species found around the spring rice fields also have ethnobotanical values. These 54 species of weeds can be either used for medicine, fodder, vegetables, fruits, pickles, or ornamental purposes. A few can also be used as Marcha (for making wine) and coffee (Senna tora (L.) Roxb.). Seven species are designated as poisonous (Annex B). Three species have religious importance and are necessary for rituals (Annex B).

RBD and F.Ac reported a relatively higher proportion of ethnobotanical uses. Both reported the ethnobotanical uses of around $62 \%$ of the subject plants. The proportion is relatively less for NRM (43\%) and M.Ad. (42\%). F.Ac. reported the medicinal value of around $30 \%$ of the plants (Figure 3). Overlapping the responses from all four key stakeholders suggests that all these plant species have some ethnobotanical values. Around $38 \%$ of the plant species (i.e., 29 plant species) have medicinal value, $34 \%$ of the plant species serve as fodder, and the remaining $28 \%$ have other uses such as vegetables, fruits, poisons, ritual, ornamental, pickles, and Marcha.

Higher professional involvement, namely, Vaidyas, resulted in greater practical plant knowledge compared to others utilizing plant resources as per need only. This suggests that practical ethnobotanical knowledge among different ethnic/caste groups does not differ substantially. What makes a difference is the continuous practice/use of the plant resources for different purposes. Hence, it is not necessary that the ethnic groups have wider knowledge in the ethnobotanical uses of the weeds reported in spring rice fields and nearby.

Out of the 29 plant species having ethnomedicine use, medicinal uses of 16 plant species are reported in previous literature (please refer to Annex C). Some of the common medicinal values include skin-related problems such as cuts, burns, and scabies, followed by respiratory problems such as cough and asthma. As a low-lying district, Chitwan is hot in the summer. Centella asiatica (L.) Urb., Hydrocotyle sibthorpioides Lam., Spirodela polyrrhiza (L.) Schleid., and Fagopyrum esculentum Moench are useful in overcoming heatstroke. Similar, ethnomedicine use was also reported by Singh et al. (2014), Bhatta and Kunwar (2020), and Pangeni et al. (2020). These species are also used to treat fever, including typhoid (Pradhan et al. 2020; Hazarika et al. 2021). Juncus prismatocarpus R.Br. and Sphaeranthus indicus L. are used for treating snake bites, whereas Monochoria vaginalis (Brum.f.) C. Presl and Monochoria hastata (L.) Solms. are used against cat/dog/tiger/jackal bites or scarring. Such ethnomedicine uses however were difficult to trace in earlier literature. This suggests that the key informants, who are also the prominent healers or Vaidyas or Guruwas in the locality, have been using many of the weeds in their local spring rice fields to treat various diseases. The key informants were using plant species for gastritis (Mazus pumilus (Burm.f.) Steenis; and Phyllanthus urinaria L.), eye related problems (Helichrysum indicum (L.) Grierson; and Polygonum plebeium R.Br), and arthritis (Commelina diffusa Burm.f.).

The informants were aware of the plants' habitat and worried that farmers consider these species useless or harmful plants in their spring rice fields. The new generation's decreasing interest in farming and use of the plant resources for day-to-day life, including medicinal uses, remain the critical concerns raised by all the key informants. This was also the case reported in several other similar studies in Nepal (Bhatt et al. 2021).

\section{Conclusion}

In the present study, 53 weed species belonging to 43 genera and 22 families were reported in the spring rice fields, while 21 others were also found in the fields' vicinity during the same season. Of the total 75 species, 54 species bear ethnobotanical values. Most of the weeds have value as medicine or fodder (i.e., 29 species medicinal and 26 fodder). Among these, six species have both medicinal and fodder value.

People of the Tharu settlement in Bangain and the Darai settlement in Mangalpur (close to IAAS farm) rely on different plant resources as the first resort for health aid. They go to a pharmacy only if the recommendations of Guruwas/Vaidyas do not work. They visit a doctor as the secondary resort. The Brahmin settlements of Champanagar and Ujjalnagar are similar. Hence, documentation of weeds' ethnobotanical uses will serve as 
valuable information for efficient use of plant resources regarded as "harmful" for main crops and, therefore, "unwanted." Moreover, the increased urbanization rate in the study areas is causing loss of agricultural land threatening not only farming, but also the ethnobotanical uses of weed species prominent in those farmlands. Thus, this study's main contribution includes documenting these ethnobotanical uses of weed species. Under the context of decreasing interest in use of plant resources for day-to-day life, this documentation will be a valuable resource for efficient management of harmful and unwanted plants, i.e., weeds. Besides, there is also a need to inform people regarding the beneficial uses of the plants, including weeds, available in their vicinity, and make such documented information readily available to the people.

The author acknowledges the age of data used to prepare this manuscript; in particular, the ecological data concerning weeds may differ from the present, primarily due to changes in land-use.

\section{Declarations}

List of Abbreviation: Not applicable

Ethics approval and consent to participate: A verbal consent to do the ecological surveys were obtained from the spring rice field owners. Similarly, key informants verbally agreed to participate in the survey and disclose their names in the any kind of publication.

Consent for publication: Not applicable.

Availability of data and materials: All relevant data are within the manuscript.

Competing interests: The author declares there is not competing interests.

Funding: This research is self-funded.

Author's contributions: The author conceptualized, implemented, analyzed, and written the manuscript.

\section{Acknowledgements}

It will be an injustice if I will not acknowledge Mr. Nanda Ram Mahato, Mr. Ram Bilas Darai, Mr. Fanindra Acharya, and Mr. Moti Lal Adhikari, the respondents for their kind cooperation during the study and sharing their invaluable knowledge regarding the plant uses. I would like to thank Mr. Santosh Raj Poudel and Ms. Sangita Poudel, my classmates, for their crucial help in conducting the surveys and their contribution in the painstaking task of characterizing the species for identification and counting each species meticulously for ecological analysis. I would like to extend my gratitude to Professor Dharma Raj Dangol for his inspiration. Lastly, I acknowledge the generous support provided by The Center for Contemporary India Studies at Hiroshima University (HINDAS) for the professional English edit of this paper.

\section{Literature cited}

Amjad, MS, Arshad M, Qureshi R. 2015. Ethnobotanical inventory and folk uses of indigenous plants from Pir Nasoora National Park, Azad Jammu and Kashmir. Asian Pacific Journal of Tropical Biomedicine 5(3):234-241.

Arunesh A, Karuppaiah P, Muraleedharan A. 2018. Ethnobotanical studies of weed plants in rice field ecosystem. Journal of Floriculture and Landscaping 4:12-14.

Bhatt MD, Adhikari YP, Kunwar RM. 2021. Ethnomedicinal values of weeds in Kanchanpur district, Far-Western Nepal. Ethnobotany Research \& Applications 21.19: 1-19. http://dx.doi.org/10.32859/era.21.19.1-19

Bhatt MD, Kunwar RM. 2020. Distribution pattern and ethnomedicinal uses of plants in Kanchanpur district, FarWestern Nepal. Ethnobotany Research and Applications 20.14: 1-21. http://dx.doi.org/10.32859/era.20.14.1-21

Bhatt MD. 2019. Distribution pattern and ecophenological studies with medicinal value of Piper longum $\mathrm{L}$. International Journal of Advanced Research 7(2):983-992.

Budha-Magar S, Bhandari P, Ghimire SK. 2020. Ethno-medicinal survey of plants used by Magar (Kham) community, Rolpa district, Western Nepal. Ethnobotany Research and Applications 19(18):1-29. http://dx.doi.org/10.32859/era.19.18.1-29

Dangol DR, Bhattarai ID. 1993. Study on the weeds of Terai rice fields in Nepal. IAAS Research Reports (1983-91) 310-316.

Dangol DR, Gurung SB, Bhattarai ID. 1986. Lowland rice weeds at the agronomy farm of IAAS, Rampur, Chitwan, Nepal. Journal of Institute of Agriculture and Animal Science 7: 1-12.

Dangol DR, Gurung SB, Bhattarai ID, Chaudhary NK. 1988. Survey of weeds of major crops at Rampur and its vicinity in Chitwan, Nepal" Journal of Institute of Agriculture and Animal Science 9: 35-43. 
FAO. 2002. FAO Rice Information, Volume 3. Food and Agriculture Organization of the United Nations Rome, Italy. GBIF Secretariat. 2021. GBIF backbone taxonomy. Checklist dataset https://doi.org/10.15468/39omei. Accessed on 16 October 2021.

Hazarika I, Mukundan GK, Sundari PS, Laloo D. 2021. Journey of Hydrocotyle sibthorpioides Lam.: From traditional utilization to modern therapeutics-A review. Phytotherapy Research 35(4):1847-1871. https://doi.org/10.1002/ptr.6924

ISE. 2006. ISE Code of Ethics (with 2008 additions). Online: http://ethnobiology.net/code-of-ethics/ Accessed on: 19 Aug 2021

Jaisi A, Marahatta S, Jha RK. 2020. Production economics and technology adoption of spring rice in Eastern Chitwan of Nepal. International Journal of Research in Agronomy 3(1): 13-18.

Manandhar NP. 1997. Ethnobotany in Nepal. In Ethnobotany for conservation and community development. Edited by KK Shrestha, PK Jha, P Shengji, A Rastogi, S Rajbhandary \& M Joshi. Ethnobotanical Society of Nepal, Kathmandu, Nepal, Pp. 22-27.

Manandhar S, Shrestha BB, Lekhak, HD. 2007. Weeds of paddy field at Kirtipur, Kathmandu. Scientific World 5(5): 100-106.

MoAD. 2015. Rice varietal mapping in Nepal: Implication for development and adoption. Ministry of Agricultural Development (MoAD), Lalitpur, Nepal.

MoALD. 2020. Statistical information in Nepalese agriculture 2075/76 [2018/19]. Ministry of Agriculture \& Livestock Development (MoALD), Kathmandu, Nepal.

Pancho JV, Kim JS. 1985. Reproductive biology of weeds in vegetables in the highlands of Benguet, Juzon, Philippines. Philippines Journal of Weed Science 12:75-98.

Pangeni B, Bhattarai S, Paudyal H, Chaudhary RP. 2020. Ethnobotanical study of Magar ethnic community of Palpa district of Nepal. Ethnobotany Research \& Application 20.44: 1-17. http://dx.doi.org/10.32859/era.20.44.1

Pradhan SP, Chaudhary RP, Sigdel S, Pandey BP. 2020. Ethnobotanical knowledge of Khandadevi and Gokulganga rural municipality of Ramechhap district of Nepal. Ethnobotany Research and Applications 20(7:)1-32. http://dx.doi.org/10.32859/era.20.07.1-32

Press JR, Shrestha KK, Sutton DA. 2000. Annotated checklist of the flowering plants of Nepal. A joint project of the natural history museum, London and Tribhuvan university, Kathmandu, Nepal.

Rijal A. 1997. Application of Ethnobotany in conservation and community development. In Ethnobotany for conservation and community development. Edited by KK Shrestha, PK Jha, P Shengji, A Rastogi, S Rajbhandary $\&$ M Joshi. Ethnobotanical Society of Nepal, Kathmandu, Nepal, Pp. 28-33.

Shengji P. 1997. Application of Ethnobotany for sustainable management of plant resource. In Ethnobotany for conservation and community development. Edited by KK Shrestha, PK Jha, P Shengji, A Rastogi, S Rajbhandary \& M Joshi. Ethnobotanical Society of Nepal, Kathmandu, Nepal, Pp. 67-72.

Shrestha KK. 1997. Ethnobotanical inventory and plant taxonomy: Basic approaches for ethnobotanical research. In Ethnobotany for conservation and community development. Edited by KK Shrestha, PK Jha, P Shengji, A Rastogi, S Rajbhandary \& M Joshi. Ethnobotanical Society of Nepal, Kathmandu, Nepal, Pp. 67-72.

Shrestha UB, Sharma KP, Devkota A, Siwakoti M, Shrestha BB. Potential impact of climate change on the distribution of six invasive alien plants in Nepal. Ecological Indicators 95(1):99-107. https://doi.org/10.1016/j.ecolind.2018.07.009

Shrestha BB, Budha PB, Wong L, Pagad S. 2020. Global register of introduced and invasive species - Nepal. Version 2.7. Invasive Species Specialist Group ISSG. Checklist dataset https://doi.org/10.15468/4rOkkr. Accessed on: 20 October 2021.

Singh $\mathrm{H}$, Husain T, Agnihotri P, Pande PC, Khatoon S. 2014. An ethnobotanical study of medicinal plants used in sacred groves of Kumaon Himalaya, Uttarakhand, India. Journal of Ethnopharmacology 154:98-108.

Swapna MM, Prakashkumar R, Anoop KP, Manju CN, Rajith NP. 2011. A review on the medicinal and edible aspects of aquatic and wetland plant of India. Journal of Medicinal Plants Research 5(33):7163-7176.

Tajkia JE, Sagar A, Sarwar AKMG. 2018. Reassessment of cyperaceous weed biodiversity at Bangladesh Agricultural University campus. Journal of Bangladesh Agricultural University 16(2):221-226.

Tennyson S, Ravindran KJ, Eapen A, William SJ. 2012. Effect of Ageratum houstonianum Mill. (Asteraceae) leaf extracts on the oviposition activity of Anopheles stephensi, Aedes aegypti and Culex quinquefasciatus (Diptera: Culicidai). Parasitology Research 111: 2295-2299. 
UN. Maps. United Nations Nepal Information Platform. Published on the Internet; http://www.un.org.np/resources/maps. Accessed on: 12 July, 2011.

WFO. World Flora Online. Published on the Internet; http://www.worldfloraonline.org. Accessed on: 6 Aug 2021.

WHO. 2019. WHO global report on traditional and complementary medicine 2019. World Health Organization, Geneva.

Yabesh JEM, Prabhu S, Vijayakumar S. 2014. An ethnobotanical study of medicinal plants used by traditional healers in silent valley of Kerala, India. Journal of Ethnopharmacology 154: 774-789.

Zobel DB, Jha PK, Behan ML, Yadav UKR. 1987. A practical manual for ecology. Ratna Book Distributor, Kathmandu, Nepal. 
Annex A. Ecological data on weeds of spring rice at IAAS and its vicinity in Chitwan. ( $D=$ Density, $A=A b u n d a n c e, F \%=F r e q u e n c y, R D=R e l a t i v e ~ D e n s i t y, ~ R A=R e l a t i v e ~ A b u n d a n c e$, $\mathrm{RF}=$ Relative Frequency, IVI = Importance Value index, SDR = Summed Dominance Ratio)

\begin{tabular}{|c|c|c|c|c|c|c|c|c|c|}
\hline Botanical name & Family & D & $\mathbf{A}$ & $\mathbf{F} \%$ & RD & RA & RF & IVI & SDR \\
\hline Spirodela polyrrhiza (L.) Schleid. & Araceae & 227.4 & 454.8 & 50 & 19.55 & 20.2 & 2.959 & 42.7 & 14.23 \\
\hline Cyperus difformis $\mathrm{L}$. & Cyperaceae & 200.7 & 200.7 & 100 & 17.25 & 8.91 & 5.917 & 32.1 & 10.69 \\
\hline Azolla Lam. & Salviniaceae & 164.2 & 328.4 & 50 & 14.12 & 14.6 & 2.959 & 31.7 & 10.55 \\
\hline Mecardonia procumbens (Mill.) Small & Plantaginaceae & 55.5 & 111.00 & 50 & 4.771 & 4.93 & 2.959 & 12.7 & 4.219 \\
\hline Fimbristylis quinquangularis (Vahl) Kunth & Cyperaceae & 43.8 & 43.8 & 100 & 3.765 & 1.94 & 5.917 & 11.6 & 3.876 \\
\hline Alternanthera sessilis (L.) R.Br. ex DC. & Amaranthaceae & 31.7 & 1.7 & 100 & 2.725 & 1.41 & 5.917 & 10.0 & 3.35 \\
\hline Paspalum distichum L. & Poaceae & 36.1 & 72.2 & 50 & 3.104 & 3.2 & 2.959 & 9.3 & 3.089 \\
\hline Lindernia anagallis (Brum.f.) Pennell & Linderniaceae & 16.3 & 163.00 & 10 & 1.401 & 7.23 & 0.592 & 9.2 & 3.076 \\
\hline Ageratum houstonianum Mill. & Compositae & 32.1 & 80.25 & 40 & 2.76 & 3.56 & 2.367 & 8.69 & 2.896 \\
\hline Eleocharis atropurpurea (Retz.) J.Presl \& C.Presl & Cyperaceae & 28.6 & 71.5 & 40 & 2.459 & 3.17 & 2.367 & 8.0 & 2.666 \\
\hline Gratiola oppositifolia L. ex Willd. & Linderniaceae & 24.3 & 34.71 & 70 & 2.089 & 1.54 & 4.142 & 7.77 & 2.591 \\
\hline Cyperus rotundus $\mathrm{L}$. & Cyperaceae & 25.1 & 50.2 & 50 & 2.158 & 2.23 & 2.959 & 7.34 & 2.448 \\
\hline Fimbristylis Vahl & Cyperaceae & 21.6 & 36.0 & 60 & 1.857 & 1.6 & 3.55 & 7.01 & 2.335 \\
\hline Digitaria ciliaris (Retz.) Koeler & Poaceae & 23.0 & 46.0 & 50 & 1.977 & 2.04 & 2.959 & 6.98 & 2.326 \\
\hline Echinochloa colona (L.) Link & Poaceae & 20.5 & 41.0 & 50 & 1.762 & 1.82 & 2.959 & 6.54 & 2.18 \\
\hline Cyperus iria L. & Cyperaceae & 9.5 & 95.0 & 10 & 0.817 & 4.22 & 0.592 & 5.63 & 1.875 \\
\hline Polycarpon prostratum (Forssk.) Asch. \& Schweinf. & Caryophyllaceae & 6.3 & 21.0 & 30 & 0.542 & 0.93 & 1.775 & 3.25 & 1.083 \\
\hline Commelina diffusa Burm.f. & Commelinaceae & 4.3 & 10.75 & 40 & 0.37 & 0.48 & 2.367 & 3.21 & 1.071 \\
\hline Schoenoplectiella supina (L.) Lye & Cyperaceae & 5.4 & 18.0 & 30 & 0.464 & 0.8 & 1.775 & 3.04 & 1.013 \\
\hline Monochoria vaginalis (Brum.f.) C. Presl & Pontederiaceae & 2.1 & 5.25 & 40 & 0.181 & 0.23 & 2.367 & 2.78 & 0.927 \\
\hline Limnophila indica (L.) Druce & Plantaginaceae & 3.5 & 1.67 & 30 & 0.301 & 0.52 & 1.775 & 2.59 & 0.865 \\
\hline Amaranthus spinosus $\mathrm{L}$. & Amaranthaceae & 1.0 & 2.5 & 40 & 0.086 & 0.11 & 2.367 & 2.56 & 0.855 \\
\hline Mollugo pentaphylla L. & Molluginaceae & 1.6 & 5.33 & 30 & 0.138 & 0.24 & 1.775 & 2.15 & 0.716 \\
\hline Helichrysum indicum (L.) Grierson & Compositae & 1.4 & 4.66 & 30 & 0.12 & 0.21 & 1.775 & 2.10 & 0.701 \\
\hline Eclipta prostrata (L.) L. & Compositae & 0.9 & 3.0 & 30 & 0.077 & 0.13 & 1.775 & 1.99 & 0.662 \\
\hline Rotala rotundifolia (Buch.-Ham. ex Roxb.) Koehne & Lythraceae & 2.6 & 13.0 & 20 & 0.224 & 0.58 & 1.183 & 1.98 & 0.661 \\
\hline Microcarpaea minima (K.D.Koenig ex Retz.) Merr. & Plantaginaceae & 2.2 & 11.00 & 20 & 0.189 & 0.49 & 1.183 & 1.86 & 0.62 \\
\hline Hedyotis L. & Rubiaceae & 1.8 & 9.00 & 20 & 0.155 & 0.4 & 1.183 & 1.74 & 0.579 \\
\hline Lindernia parviflora (Roxb.) Haines & Linderniaceae & 1.1 & 5.5 & 20 & 0.095 & 0.24 & 1.183 & 1.52 & 0.507 \\
\hline
\end{tabular}


Ethnobotany Research and Applications

\begin{tabular}{|c|c|c|c|c|c|c|c|c|c|}
\hline Cyperus compressus $\mathrm{L}$. & Cyperaceae & 0.8 & 4.0 & 20 & 0.069 & 0.18 & 1.183 & 1.43 & 0.477 \\
\hline Schoenoplectiella erecta (Poir.) Lye & Cyperaceae & 1.4 & 14.0 & 10 & 0.12 & 0.62 & 0.592 & 1.33 & 0.444 \\
\hline Ludwigia hyssopifolia (G.Don.) Exell & Onagraceae & 0.4 & 0.4 & 20 & 0.034 & 0.09 & 1.183 & 1.31 & 0.436 \\
\hline Chenopodium album $\mathrm{L}$. & Amaranthaceae & 0.3 & 1.5 & 20 & 0.026 & 0.07 & 1.183 & 1.28 & 0.425 \\
\hline Fimbristylis dichotoma (L.) Vahl & Cyperaceae & 0.8 & 8.0 & 10 & 0.069 & 0.36 & 0.592 & 1.02 & 0.339 \\
\hline Cyperus L. & Cyperaceae & 0.7 & 7.0 & 10 & 0.60 & 0.31 & 0.592 & 0.96 & 0.321 \\
\hline Scoparia dulcis L. & Plantaginaceae & 0.6 & 6.00 & 10 & 0.052 & 0.27 & 0.592 & 0.91 & 0.303 \\
\hline Cyperus tenuiculmis Boeckeler & Cyperaceae & 0.5 & 5.0 & 10 & 0.043 & 0.22 & 0.592 & 0.86 & 0.286 \\
\hline Mazus pumilus (Burm.f.) Steenis & Phrymaceae & 0.5 & 5.00 & 10 & 0.043 & 0.22 & 0.592 & 0.86 & 0.286 \\
\hline Fagopyrum esculentum Moench & Polygonaceae & 0.3 & 3.0 & 10 & 0.026 & 0.13 & 0.592 & 0.75 & 0.25 \\
\hline Persicaria barbata (L.) H.Hara & Polygonaceae & 0.3 & 3.00 & 10 & 0.026 & 0.13 & 0.592 & 0.75 & 0.25 \\
\hline Centella asiatica (L.) Urb. & Apiaceae & 0.1 & 1.0 & 10 & 0.009 & 0.04 & 0.592 & 0.64 & 0.215 \\
\hline Hydrocotyle sibthorpioides Lam. & Araliaceae & 0.1 & 1.0 & 10 & 0.009 & 0.04 & 0.592 & 0.64 & 0.215 \\
\hline Centipeda minima (L.) A.Braun \& Asch. & Compositae & 0.1 & 1.0 & 10 & 0.009 & 0.04 & 0.592 & 0.64 & 0.215 \\
\hline Acmella paniculata (Wall. ex DC.) R. K. Jansen & Compositae & 0.1 & 1.0 & 10 & 0.009 & 0.04 & 0.592 & 0.64 & 0.215 \\
\hline Senna tora (L.) Roxb. & Fabaceae & 0.1 & 1.0 & 10 & 0.009 & 0.04 & 0.592 & 0.64 & 0.215 \\
\hline Pisum sativum $\mathrm{L}$. & Fabaceae & 0.1 & 1.0 & 10 & 0.009 & 0.04 & 0.592 & 0.64 & 0.215 \\
\hline Vicia sativa subsp. nigra (L.) Ehrh. & Fabaceae & 0.1 & 1.0 & 10 & 0.009 & 0.04 & 0.592 & 0.64 & 0.215 \\
\hline Rotala indica (Willd.) Koehne & Lythraceae & 0.1 & 1.0 & 10 & 0.009 & 0.04 & 0.592 & 0.64 & 0.215 \\
\hline Phyla nodiflora (L.) Greene & Verbenaceae & 0.1 & 1.00 & 10 & 0.009 & 0.04 & 0.592 & 0.64 & 0.215 \\
\hline
\end{tabular}


Annex B. Ethnobotanical value of weeds found in and around the spring rice fields. (Th $=$ Tharu, $\mathrm{M}=$ Medicine, $\mathrm{V}=\mathrm{Vegetables}, \mathrm{R}=\mathrm{Religious}, \mathrm{Pi}=\mathrm{Pickle}, \mathrm{D}=\mathrm{Darai}, \mathrm{Po}=\mathrm{Poison}$, $\mathrm{Fr}=$ Fruit, $\mathrm{Or}=$ Ornamental, $\mathrm{Bh}=$ Brahmin, $\mathrm{F}=$ Fodder, $\mathrm{Ma}=$ Marcha)

\begin{tabular}{|c|}
\hline Botanical name \\
\hline Alternanthera sessilis (L.) R.Br. ex DC. * \\
\hline Amaranthus spinosus $\mathrm{L} .{ }^{*}$ \\
\hline Chenopodium album L. * \\
\hline Centella asiatica (L.) Urb. * \\
\hline Hydrocotyle sibthorpioides Lam. * \\
\hline Spirodela polyrrhiza (L.) Schleid. * \\
\hline Ageratum houstonianum Mill. * \\
\hline Eclipta prostrata (L.) L. * \\
\hline Helichrysum indicum (L.) Grierson * \\
\hline Acmella paniculata (Wall. ex DC.) R. K. Jansen * \\
\hline Polycarpon prostratum (Frossk.) Asch. \& Schweinf. * \\
\hline Commelina diffusa Burm.f. * \\
\hline Cyperus compressus L. * \\
\hline Cyperus difformis L. * \\
\hline Cyperus tenuiculmis Boeckeler * \\
\hline Eleocharis atropurpurea (Retz.) J.Presl \& C.Presl * \\
\hline Fimbristylis quinquangularis (Vahl) Kunth * \\
\hline Fimbristylis Vahl * \\
\hline Schoenoplectiella supina (L.) Lye * \\
\hline Senna tora (L.) Roxb. ${ }^{*}$ \\
\hline Pisum sativum $\mathrm{L} .{ }^{*}$ \\
\hline Juncus prismatocarpus $\mathrm{R} . \mathrm{Br} .{ }^{*}$ \\
\hline Lindernia anagallis (Brum.f.) Pennell * \\
\hline Gratiola oppositifolia L. ex Willd. \\
\hline Rotala rotundifolia (Buch.-Ham. ex Roxb.) Koehne * \\
\hline Mazus pumilus (Burm.f.) Steenis * \\
\hline Cynodon dactylon (L.) Pers. * \\
\hline
\end{tabular}

\section{Local name}

Chimke jhar (Bh)

Lunde (Bh), kataiya (Th)

Bethe (Bh), bethua (D\Th)

Ghode tapre (Bh), ghortapua (Th)

Sano amili chari jhar (Bh),

pothi ghode tapre (D), tarpurin (Th)

Ghole tapre (Bh), surabir (D)

Bokeban (D), dandhe jhar/jhangi (Bh/Th)

Bhringaraj (Bh), bhugurna (Th)

Buke jhangi (D), buke phool (Bh), darangi (Th)

Tite jhar (Bh), bador-kador (D), rudhilo (Bh)

Chimke jhar (Bh), bhebhurna (D)

Kane jhangi/jhar (D/Bh), gerguj (Th)

Chiure jhar (Bh)

Sano mothe (Bh), mothe (D/Th)

Thulo mothe (Bh), pani mothe (D)

dhabbwala mothe (Bh)

Fuli jhar/Chandani jhar (Bh)

Thulo jwane jhar/jhangi (Bh/D), jhusuna (Th)

Kharra jwane sama (Bh),

bhend raunwa (D)

Suire jhar (Bh), sosa (Th), suri (D)

Tapre (Bh/D), chakror (Th)

Jangalikerau (D), chimtakerau (Th)

Tauke jhar (Bh)

Kanchi saag (Bh)

Chimke jhar/ jiliot pati (Bh),

harhatch saag (Th)

Runia (Bh)

Chini jhar (Bh)

Dubo (D/Th), sano dubo (Bh)

\begin{tabular}{|l|l|l|l|l|}
\hline Family & NRM & RBD & F.Ac. & M.Ad \\
\hline Amaranthaceae & - & - & F/M & - \\
\hline Amaranthaceae & - & - & $\mathrm{V}$ & $\mathrm{M} / \mathrm{V}$ \\
\hline Amaranthaceae & $\mathrm{V}$ & $\mathrm{V}$ & $\mathrm{V}$ & $\mathrm{V}$ \\
\hline Apiaceae & $\mathrm{M}$ & $\mathrm{M}$ & - & $\mathrm{M}$ \\
\hline Araliaceae & $\mathrm{F}$ & $\mathrm{F} / \mathrm{M}$ & $\mathrm{F}$ & $\mathrm{F}$ \\
& & & & \\
\hline Araceae & - & $\mathrm{M}$ & $\mathrm{M}$ & - \\
\hline Compositae & $\mathrm{M} / \mathrm{Po}$ & $\mathrm{M}$ & - & - \\
\hline Compositae & $\mathrm{M}$ & - & - & $\mathrm{M}$ \\
\hline Compositae & - & $\mathrm{M}$ & - & $\mathrm{F}$ \\
\hline Compositae & - & $\mathrm{Fr}$ & $\mathrm{M}$ & - \\
\hline Caryophyllaceae & - & $\mathrm{M}$ & $\mathrm{F} / \mathrm{M}$ & - \\
\hline Commelinaceae & - & $\mathrm{F}$ & $\mathrm{M}$ & $\mathrm{F}$ \\
\hline Cyperaceae & - & - & - & $\mathrm{F}$ \\
\hline Cyperaceae & $\mathrm{F}$ & $\mathrm{F}$ & $\mathrm{F}$ & $\mathrm{F}$ \\
\hline Cyperaceae & - & $\mathrm{F}$ & $\mathrm{F}$ & - \\
\hline Cyperaceae & - & - & $\mathrm{Or}$ & $\mathrm{Or}$ \\
\hline Cyperaceae & - & $\mathrm{F} / \mathrm{M}$ & - & - \\
\hline Cyperaceae & - & $\mathrm{F}$ & $\mathrm{M}$ & - \\
& & & & \\
\hline Cyperaceae & $\mathrm{F}$ & $\mathrm{M}$ & - & $\mathrm{F}$ \\
\hline Fabaceae & - & $\mathrm{F}$ & $\mathrm{Coffee}$ & - \\
\hline Fabaceae & - & $\mathrm{Pi} / \mathrm{Fr}$ & - & - \\
\hline Juncaceae & - & - & $\mathrm{M} / \mathrm{Po}$ & - \\
\hline Linderniaceae & - & - & - & $\mathrm{V}$ \\
\hline Linderniaceae & $\mathrm{V}$ & $\mathrm{F} / \mathrm{M}$ & - & - \\
\hline Lythraceae & - & - & $\mathrm{M}$ & - \\
\hline Phrymacee & - & - & $\mathrm{M}$ & - \\
\hline Poaceae & $\mathrm{R}$ & $\mathrm{R}$ & - & $\mathrm{F} / \mathrm{M} / \mathrm{R}$ \\
\hline
\end{tabular}




\begin{tabular}{|c|c|c|c|c|c|c|}
\hline Digitaria ciliaris (Retz.) Koeler * & Jhuse jhangi (D) & Poaceae & - & $\mathrm{F}$ & - & - \\
\hline Echinocloa colonum (L.) Link. * & $\begin{array}{l}\text { Sama banso }(B h), \text { sama }(T h), \\
\text { pani sama }(D)\end{array}$ & Poaceae & $\mathrm{F}$ & - & - & $\mathrm{F}$ \\
\hline Paspalum distichum $\mathrm{L} .{ }^{*}$ & Pani kane (D), suiri ghaans (Th) & Poaceae & $\mathrm{F}$ & $\mathrm{F}$ & - & - \\
\hline Fagopyrum esculentum Moench * & Faper (D) & Polygonaceae & - & $M$ & - & - \\
\hline Persicaria barbata (L.) H.Hara * & Pirre jhar (Bh), totera (Th), blesendhari (D) & Polygonaceae & Po & $M$ & M & Po \\
\hline Monochoria vaginalis (Brum.f.) C. Presl * & Baans pate $(T h)$, tarpurain $(D)$ & Pontederaceae & $\mathrm{F}$ & - & M & - \\
\hline Caesulia axillaris Roxb. ** & $\begin{array}{l}\text { Khotila jhangi (Th), } \\
\text { kumale jhar (Bh) }\end{array}$ & Compositae & - & - & Po & - \\
\hline Laphangium luteoalbum (L.) Tzvelev ** & Buke phool (Bh), phohori (Th) & Compositae & Po & - & - & - \\
\hline Sphaeranthus indicus L. ** & $\begin{array}{l}\text { Tauke jhar (Bh), khattesari (Th), } \\
\text { Jangali marahathi jhangi (D) }\end{array}$ & Compositae & - & M & $\mathrm{M} / \mathrm{Po}$ & - \\
\hline Xanthium strumarium $\mathrm{L}$. ** & $\begin{array}{l}\text { Bhende kuro / madeshe kuro (Bh), Chidchidia/ } \\
\text { khanger (Th), khangro (D) }\end{array}$ & Compositae & - & - & M & - \\
\hline Cleome viscosa $\mathrm{L}$. ** & Bantori (Bh) & Cleomaceae & - & $\mathrm{Ma}$ & $\mathrm{Po} / \mathrm{Ma}$ & - \\
\hline Ipomoea aquatica Forssk. ** & Ajambari jhar (Bh), farmaiya (Th), karami (D) & Convulvulaceae & - & $\mathrm{V}$ & $\mathrm{V}$ & $\mathrm{M} / \mathrm{V}$ \\
\hline Euphorbia hirta L. ** & $\begin{array}{l}\text { Tika jhangi (Th), dudhe jhar (Bh), } \\
\text { rani dubo (D) }\end{array}$ & Euphorbiaceae & M & - & - & - \\
\hline Salvia plebeia R.Br. ** & Halhale (Bh), jhuse jhangi (D) & Lamiaceae & - & - & $\mathrm{V}$ & - \\
\hline Phyllanthus urinaria L. ** & Bhiun amala (Bh), amita (Th) & Phyllanthaceae & $\mathrm{F}$ & - & M & - \\
\hline Echinochloa crus-galli (L.) P. Beauv. ${ }^{* *}$ & Kathe sama (Bh), paterigandir (D) & Poaceae & - & $\mathrm{F}$ & $\mathrm{R}$ & $\mathrm{F} / \mathrm{R}$ \\
\hline Eleusine indica (L.) Gaertn. ** & Kode jhar (Bh), dande jhangi (D) & Poaceae & $\mathrm{F}$ & $\mathrm{F}$ & $\mathrm{F}$ & $\mathrm{F}$ \\
\hline Eragrostis gangetica (Roxb.) Steud. ** & Ghobe banso (Bh), bhote dubo (D), chari dana (Th) & Poaceae & $\mathrm{F}$ & $\mathrm{F}$ & - & - \\
\hline Hemarthria compressa (L.f.) R. Br. ${ }^{* \star}$ & Ghode dubo (Bh), gandir (D/Th) & Poaceae & $\mathrm{F}$ & $\mathrm{F}$ & $\mathrm{F}$ & $\mathrm{F}$ \\
\hline Isachne globosa (Thunb.) Kuntze ** & $\begin{array}{l}\text { Sano banso }(\mathrm{Bh}) \text {, } \\
\text { sano ghode dubo }(\mathrm{Bh}) \text {, sora }(\mathrm{Th})\end{array}$ & Poaceae & - & - & $\mathrm{F}$ & $\mathrm{F}$ \\
\hline Leersia hexandra Sw. ${ }^{* *}$ & Karaunte jhar (Bh), chaleni (D/Th), madeshe jhar (Bh), & Poaceae & $\mathrm{F}$ & $\mathrm{F}$ & $\mathrm{R}$ & $\mathrm{R}$ \\
\hline Paspalum dilatatum Poir. ** & Kode ghaans (Bh), mane jhangi (D), sawa (Th) & Poaceae & $\mathrm{F}$ & $\mathrm{F}$ & $\mathrm{F}$ & $\mathrm{F}$ \\
\hline Setaria pumila (Poir.) Roem. \& Schult. ** & $\begin{array}{l}\text { Bale banso (Bh), kagune banso (Bh), bander puchre } \\
\text { (D/Th) }\end{array}$ & Poaceae & $\mathrm{F}$ & $\mathrm{F}$ & $\mathrm{F}$ & $\mathrm{F}$ \\
\hline Persicaria lanigera (R.Br.) Soják ** & Totaban (D), totayar (Th) & Polygonaceae & - & Or & - & - \\
\hline Polygonum plebeium R.Br. ** & Sukul jhar (Bh), gogainri jhangi (D) & Polygonaceae & - & - & M & - \\
\hline Monochoria hastata (L.) Solms ** & $\begin{array}{l}\text { Pate karkalo (Bh), pipal pate (Bh), chindhodaya (Th), } \\
\text { pani karkalo(D) }\end{array}$ & Pontederiaceae & - & - & $M$ & - \\
\hline Solanum americanum Mill.. ** & Kali gedi (Th) & Solanaceae & V & - & - & - \\
\hline
\end{tabular}

Notes: ${ }^{*}$ species found in the spring rice fields and ${ }^{* *}$ species found around the spring rice fields. 


\section{Ethnobotany Research and Applications}

Annex C. Medicinal uses of weeds found in and around the spring rice fields

\begin{tabular}{|c|c|c|c|c|c|}
\hline Family & Species & Local name & Methods of use & Medicinal value & $\begin{array}{l}\text { Uses in earlier } \\
\text { references }\end{array}$ \\
\hline Amaranthaceae & $\begin{array}{l}\text { Alternanthera sessilis (L.) R.Br. } \\
\text { ex DC. * }\end{array}$ & Chimke jhar & Plant juice except root & Cold and cough & $\begin{array}{l}\text { Piles, abortion, and } \\
\text { increasing energy } \\
\text { (Yabesh et al. 2014); } \\
\text { Asthma, pneumonia, and } \\
\text { bronchitis (Arunesh et al. } \\
\text { 2018; Swapna et al. } \\
\text { 2011); } \\
\text { Wounds, venereal } \\
\text { disease, and menstrual } \\
\text { disorder (Bhatt \& } \\
\text { Kunwar 2020; Bhatt et al. } \\
\text { 2021) }\end{array}$ \\
\hline Amaranthaceae & Amaranthus spinosus L. * & Lunde & Matured plant juice & Regulation in urination & $\begin{array}{l}\text { Skin allergy (Yabesh et } \\
\text { al. 2014); } \\
\text { Diarrhea (Arunesh et al. } \\
\text { 2018; Bhatt et al. 2021); } \\
\text { Toothache, eczema, and } \\
\text { urinary troubles } \\
\text { (Arunesh et al. 2018); } \\
\text { Cough, common cold, } \\
\text { and dizziness (Pangeni } \\
\text { et al. 2020); } \\
\text { Internal bleeding, } \\
\text { excessive menstruation, } \\
\text { snake bites, boils, } \\
\text { stomach disorders, } \\
\text { mouth ulcers, and } \\
\text { gonorrhea (Bhatt et al. } \\
\text { 2021) }\end{array}$ \\
\hline Apiaceae & Centella asiatica (L.) Urb. * & Ghod tapre & Leaf juice & $\begin{array}{l}\text { Typhoid, fever, urinary disorder, } \\
\text { heatstroke (Garmigadeko), } \\
\text { treatment for alcoholic tipsiness }\end{array}$ & $\begin{array}{l}\text { Memory power (Anuresh } \\
\text { et al. 2018; Swapna et al. }\end{array}$ \\
\hline
\end{tabular}




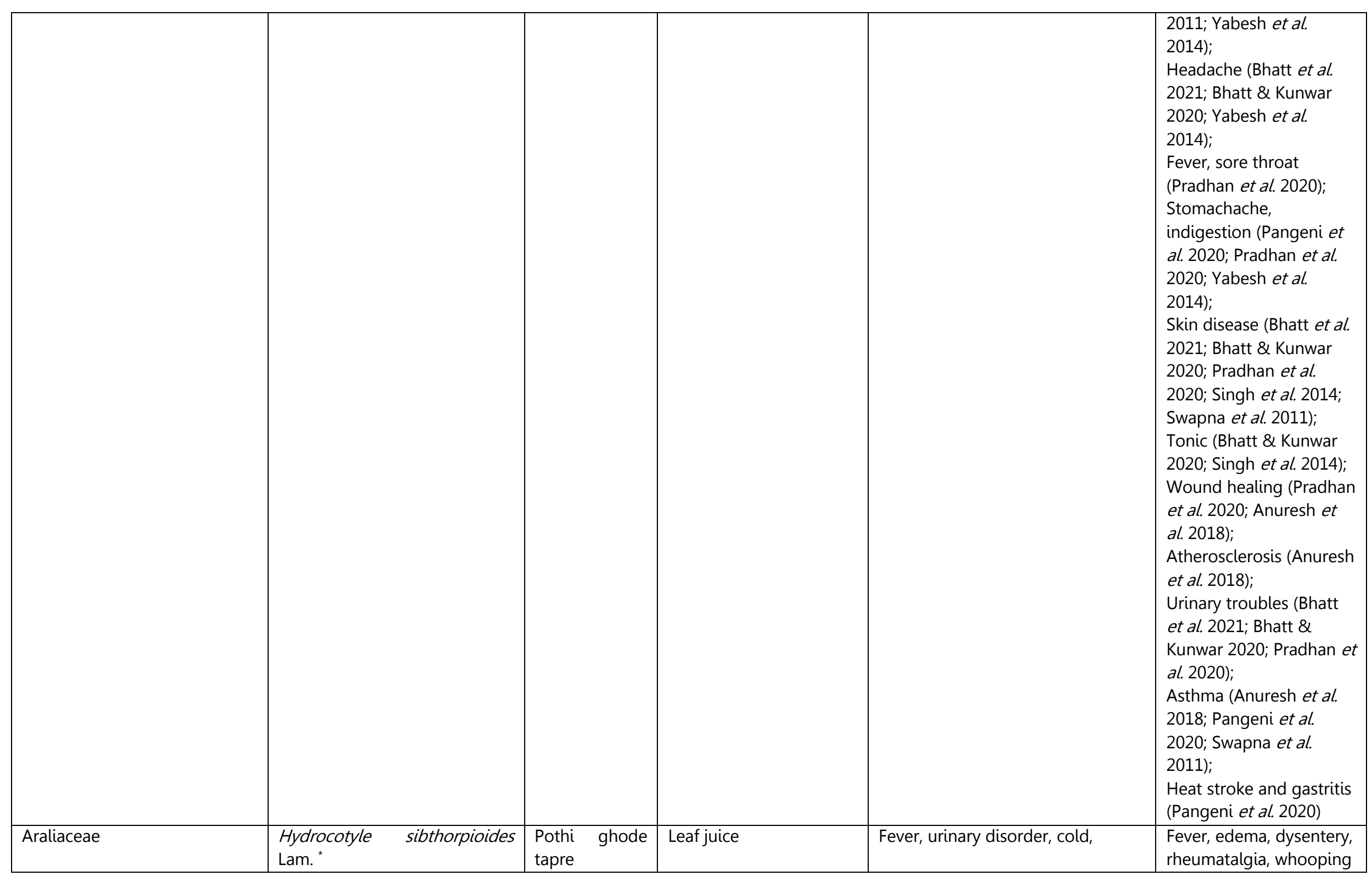


Ethnobotany Research and Applications

\begin{tabular}{|c|c|c|c|c|c|}
\hline & & & & $\begin{array}{l}\text { heatstroke } \quad \text { (Garmigadeko), } \\
\text { treatment for alcoholic tipsiness }\end{array}$ & $\begin{array}{l}\text { cough, jaundice, throat } \\
\text { pain, psoriasis, herpes } \\
\text { zoster infection, } \\
\text { hepatitis-B infection, } \\
\text { soothing pain, } \\
\text { dysmenorrhea, } \\
\text { carbunculosis, brain } \\
\text { tonic, detoxifying agent, } \\
\text { and hepatoprotective } \\
\text { agent (Hazarika et al. } \\
\text { 2021) }\end{array}$ \\
\hline Compositae & Eclipta prostrata (L.) L. & Bhringaraj & $\begin{array}{l}\text { Plant juice/Tender leaves } \\
\text { as vegetables }\end{array}$ & $\begin{array}{l}\text { Wounds due to mud, pimples, } \\
\text { sexually transmitted diseases (Yoni } \\
\text { rog) / Night blindness }\end{array}$ & $\begin{array}{l}\text { Reduce body heat } \\
\text { (Yabesh et al. 2014); } \\
\text { Headache and hair } \\
\text { growth (Yabesh et al. } \\
\text { 2014; Swapna et al. } \\
\text { 2011); } \\
\text { Cut wounds, skin } \\
\text { diseases and pimples, } \\
\text { night blindness and } \\
\text { jaundice (Bhatt \& } \\
\text { Kunwar 2020); } \\
\text { Dysentery (Pangeni et al. } \\
\text { 2020); } \\
\text { Snake bite, antibacterial, } \\
\text { and antioxidant (Bhatt et } \\
\text { al. 2021); } \\
\text { Ulcer, tonic, deobstruent } \\
\text { in hepatic and spleen } \\
\text { enlargement, skin } \\
\text { diseases, catarrhal } \\
\text { jaundice, catarrhal in }\end{array}$ \\
\hline
\end{tabular}


Ethnobotany Research and Applications

\begin{tabular}{|c|c|c|c|c|c|}
\hline & & & & & $\begin{array}{l}\text { infants, toothache, } \\
\text { eczema, and relief of } \\
\text { pain from scorpion } \\
\text { sting (Swapna et al. } \\
\text { 2011) }\end{array}$ \\
\hline Compositae & $\begin{array}{l}\text { Helichrysum indicum } \\
\text { Grierson * }\end{array}$ & Buke phool & Plant juice & Cuts (to clot blood) & \\
\hline Compositae & $\begin{array}{l}\text { Acmella paniculata (Wall. ex } \\
\text { DC.) R. K. Jansen * }\end{array}$ & Rudhilo & Plant juice, crush leaves & Burns (boil), wounds & \\
\hline Caryophyllaceae & $\begin{array}{l}\text { Polycarpon prostratum } \\
\text { (Frossk.) Asch. \& Schweinf. }{ }^{*}\end{array}$ & Chimke jhar & Plant juice except root & Wounds caused by mud & \\
\hline Commelinaceae & Commelina diffusa Burm.f. ${ }^{*}$ & Kane jhangi & Rhizome paste & Rheumatism (Aankhle) & $\begin{array}{l}\text { Burns, itches, and boils } \\
\text { (Swapna et al. 2011) }\end{array}$ \\
\hline Cyperaceae & $\begin{array}{l}\text { Fimbristylis quinquangularis } \\
\text { (Vahl) Kunth * }\end{array}$ & $\begin{array}{l}\text { Thulo jwane } \\
\text { jhangi }\end{array}$ & $\begin{array}{l}\text { Seed }+ \text { Bark of Saaj } \\
\text { (Terminalia } \\
\text { Willd.) }\end{array}$ & Whooping cough & Fever (Tajkia et al. 2018) \\
\hline Cyperaceae & Fimbristylis Vahl * & $\begin{array}{l}\text { Kharra jwone } \\
\text { sama }\end{array}$ & Boiled seed in water & Headache & \\
\hline Cyperaceae & $\begin{array}{l}\text { Schoenoplectiella supina (L.) } \\
\text { Lye * }\end{array}$ & Suri & Rhizome juice & Fever in pregnant woman & \\
\hline Juncaceae & Juncus prismatocarpus R.Br. ${ }^{*}$ & Tauke jhar & Leaf juice & Snake bite & \\
\hline Araceae & $\begin{array}{l}\text { Spirodela polyrrhiza } \quad \text { (L.) } \\
\text { Schleid. }{ }^{*}\end{array}$ & Ghol tapre & Leaf juice & $\begin{array}{l}\text { Typhoid, fever, urinary disorder, } \\
\text { heatstroke (Garmigadeko), } \\
\text { treatment for alcoholic tipsiness }\end{array}$ & \\
\hline Lythraceae & $\begin{array}{l}\text { Rotala rotundifolia (Buch.- } \\
\text { Ham. ex Roxb.) Koehne }{ }^{*}\end{array}$ & Runia & Tender leaves juice & Chest pain, asthma & $\begin{array}{l}\text { Cough, cold, and fever } \\
\text { (Swapna et al. 2011) }\end{array}$ \\
\hline Poaceae & Cynodon dactylon (L.) Pers. * & Duboo & $\begin{array}{l}\text { Plant juice/Plant juice }+ \\
\text { Lemon juice }\end{array}$ & $\begin{array}{l}\text { Cuts (to stop bleeding)/ Fracture } \\
\text { (Massage) }\end{array}$ & $\begin{array}{l}\text { Blood purifier (Amjad et } \\
\text { al. 2015; Bhatt et al. } \\
\text { 2021; Yabesh et al. } \\
\text { 2014); } \\
\text { Control nosebleed, stop } \\
\text { bleeding, and as topical } \\
\text { anti-septic (Amjad et al. } \\
\text { 2015; Bhatt et al. 2021); } \\
\text { gastritis (Yabesh et al. } \\
\text { 2014); }\end{array}$ \\
\hline
\end{tabular}




\begin{tabular}{|c|c|c|c|c|c|}
\hline Dolvannacoas & Fanonyrum scrulantum & Fanor & Plant 20 a & & $\begin{array}{l}\text { Vomiting (Bhatt et al. } \\
\text { 2021; Singh et al. 2014); } \\
\text { Jaundice, diuretic (Singh } \\
\text { et al. 2014); } \\
\text { Leukoderma, bronchitis, } \\
\text { piles, asthma, tumors, } \\
\text { skin diseases (Arunesh et } \\
\text { al. 2018); } \\
\text { Fever (Budha-Magar et } \\
\text { al. 2020); } \\
\text { Fractures (Bhatt \& } \\
\text { Kunwar 2020); } \\
\text { Cuts and wounds (Bhatt } \\
\text { \& Kunwar 2020; Pradhan } \\
\text { et al. 2020); } \\
\text { Urinary and bladder } \\
\text { complaints (Pradhan et } \\
\text { al. 2020); } \\
\text { Anti-diabetic effect } \\
\text { (Bhatt et al. 2021) }\end{array}$ \\
\hline Pontederiaceae & $\begin{array}{l}\text { Monochoria vaginalis (Brum.f.) } \\
{\text { C. Presl }{ }^{*}}\end{array}$ & Bans pate & Milky latex & $\begin{array}{l}\text { Cat, dog, tiger, jackal bite or } \\
\text { scarring }\end{array}$ & \\
\hline Linderniaceae & $\begin{array}{l}\text { Gratiola oppositifolia L. ex } \\
\text { Willd. }\end{array}$ & Chimke jhar & Plant juice except root & Cold and cough & $\begin{array}{l}\text { Dysentery and intestinal } \\
\text { problems (Bhatt } \text { et al. } \\
\text { 2021; Bhatt \& Kunwar } \\
\text { 2020) }\end{array}$ \\
\hline Phrymaceae & $\begin{array}{l}\text { Mazus pumilus (Burm.f.) } \\
\text { Steenis * }\end{array}$ & Chini jhar & Leaf and stem & Gastritis & \\
\hline
\end{tabular}


Ethnobotany Research and Applications

\begin{tabular}{|c|c|c|c|c|c|}
\hline Compositae & Sphaeranthus indicus L. ${ }^{* *}$ & Tauke jhar & Leaf juice & $\begin{array}{l}\text { Snake bite, chocking (Ghanti ma } \\
\text { kehi aadkiyama) }\end{array}$ & \\
\hline Compositae & Xanthium strumarium L. ${ }^{* *}$ & Bhende kuro & Fruit and Dhaturo & Mental disorder & $\begin{array}{l}\text { Skin treatment, anti- } \\
\text { inflammatory, and } \\
\text { antibacterial properties } \\
\text { (Bhatt et al. 2021) }\end{array}$ \\
\hline Convulvulaceae & Ipomoea aquatica Forssk. ${ }^{\star *}$ & Ajambari jhar & $\begin{array}{l}\text { Young shoots/ leaves } \\
\text { extract }\end{array}$ & Cure for diabetes/cough & \\
\hline Euphorbiaceae & Euphorbia hirta L. ${ }^{* \star}$ & Dudhe jhar & Plant & Paralysis & $\begin{array}{l}\text { Asthma (Arunesh et al. } \\
\text { 2018; Yabesh et al. } \\
\text { 2014); Cough, snake } \\
\text { bites, and lip cracks } \\
\text { (Yabesh et al. 2014); } \\
\text { Cancer, bronchial } \\
\text { infections, abscesses } \\
\text { (Arunesh et al. 2018); } \\
\text { Wounds, skin diseases, } \\
\text { and boils (Bhatt et al. } \\
\text { 2021; Bhatt \& Kunwar } \\
\text { 2020) }\end{array}$ \\
\hline Phyllanthaceae & Phyllanthus urinaria L. ${ }^{* *}$ & Bhuin amala & Plant juice & Gastritis and diarrhea & $\begin{array}{l}\text { Diuretic and appetite } \\
\text { stimulator (Bhatt et al. } \\
\text { 2021; Bhatt \& Kunwar } \\
\text { 2020) }\end{array}$ \\
\hline \multirow[t]{2}{*}{ Pontederiaceae } & $\underset{\star \star *}{\text { Monochoria hastata (L.) Solms. }}$ & Pipal pate & Milky latex & $\begin{array}{l}\text { Cat, dog, tiger, jackal bite or } \\
\text { scarring }\end{array}$ & \\
\hline & & & Leaf juice & Scabies & \\
\hline Polygonaceae & Polygonum plebeium R.Br. ${ }^{* *}$ & Sukul jhar & Plant juice & $\begin{array}{l}\text { Eye swelling (Aankha ma phulo } \\
\text { pareko) }\end{array}$ & \\
\hline
\end{tabular}

Note: ${ }^{*}$ species found in the spring rice fields and ${ }^{* *}$ species found around the spring rice fields. 
